\title{
Multi-input single-phase grid-connected inverter for hybrid PV/wind power system
}

\author{
Yahong Yang ${ }^{1,2}$, Xiaobin $\mathrm{He}^{1}$, Riming Shao ${ }^{2}$, Shuang $\mathrm{Xu}^{2}$, Liuchen Chang ${ }^{2, *}$ \\ ${ }^{1}$ Shanghai Institute of Space Power-Sources, 2965 Dongchuan Road, Shanghai, 200245, China \\ ${ }^{2}$ Department of Electrical and Computer Engineering, University of New Brunswick, Fredericton, NB, Canada E3B 5A3
}

\section{Email address:}

lchang@unb.ca (Liuchen Chang)

\section{To cite this article:}

Yahong Yang, Xiaobin He, Riming Shao, Shuang Xu, Liuchen Chang. Multi-Input Single-Phase Grid-Connected Inverter for Hybrid PV/Wind Power System. International Journal of Renewable and Sustainable Energy. Vol. 3, No. 2, 2014, pp. 35-42.

doi: 10.11648/j.ijrse.20140302.11

\begin{abstract}
This paper presents a multi-input single-phase grid-connected inverter for a hybrid photovoltaic (PV)/wind power system, integrated with basic and advanced functions developed by the authors. To achieve high quality current and fast dynamic response to inherent variations of hybrid renewable energy sources, an improved space vector pulse-width-modulation (PWM) based predictive current control algorithm is developed. Moreover, comprehensive system protection functions are implemented for practical applications. Experimental results have validated the developed multi-input inverter performance. Currently, the multi-input inverters are operating in numerous commercial installations in North America.
\end{abstract}

Keywords: Grid-Connected Inverter, Multiple-Input, Advanced Control, Distributed Generation, Renewable Energy Systems

\section{Introduction}

Applications with photovoltaic (PV) energy and wind energy have rapidly increased in response to concerns about global climate change and energy sources. However, both solar PV and wind suffer from the intermittent nature of their resources. More and more PV systems are combined with wind turbines forming hybrid PV/wind systems as these two sources complement each other reducing storage requirements [1]. Also, a hybrid PV/wind system can provide higher reliability and deliver more overall energy than either source individually $[2,3]$.

Typically, a hybrid PV/wind power system requires separate inverters for the PV array and the wind turbine respectively [4]. As an alternative approach, the multi-input inverter combines these renewable energy sources on the dc bus, while the ac side shares a common grid-side inverter injecting the power of all sources into the grid, thereby simplifying the hybrid PV/wind power system and reducing costs. While there were publications on multi-input inverters and their control methodologies, very few have been providing comprehensive descriptions of essential and advanced control and protection functions of these converters, along with complete testing results.
The purpose of this paper is to present a multi-input single-phase grid-connected inverter for a hybrid $\mathrm{PV} /$ wind power system, with an emphasis on the specially developed current control algorithm. The proposed multi-input inverter has the following advantages: 1) transmit power from the PV array and the wind turbine to the grid individually or simultaneously, 2) implement the maximum power point tracking (MPPT) feature in both solar and wind energy, and 3) allow renewable power supply systems to operate with a large range of input voltage variations.

\section{Multi-Input System Topology}

The multi-input inverter system topology is shown in Figure 1. It consists of a PV array and wind turbine used as power sources, boost choppers used as input converter modules, dc link bus capacitors, a full-bridge dc/ac converter, and a grid [5]. In this multi-input system, by applying the pulse-width-modulation (PWM) control scheme with appropriate MPPT algorithms to the boost choppers, the multi-input dc/dc converters (i.e. choppers) can extract maximum power from both the PV array and wind turbine 
individually and simultaneously. Meanwhile, the dc link voltage will be regulated by the dc/ac inverter with space vector PWM (SVPWM) based predictive current control to maintain the input-output power balance and to decouple the front-end converters and the grid inverter.

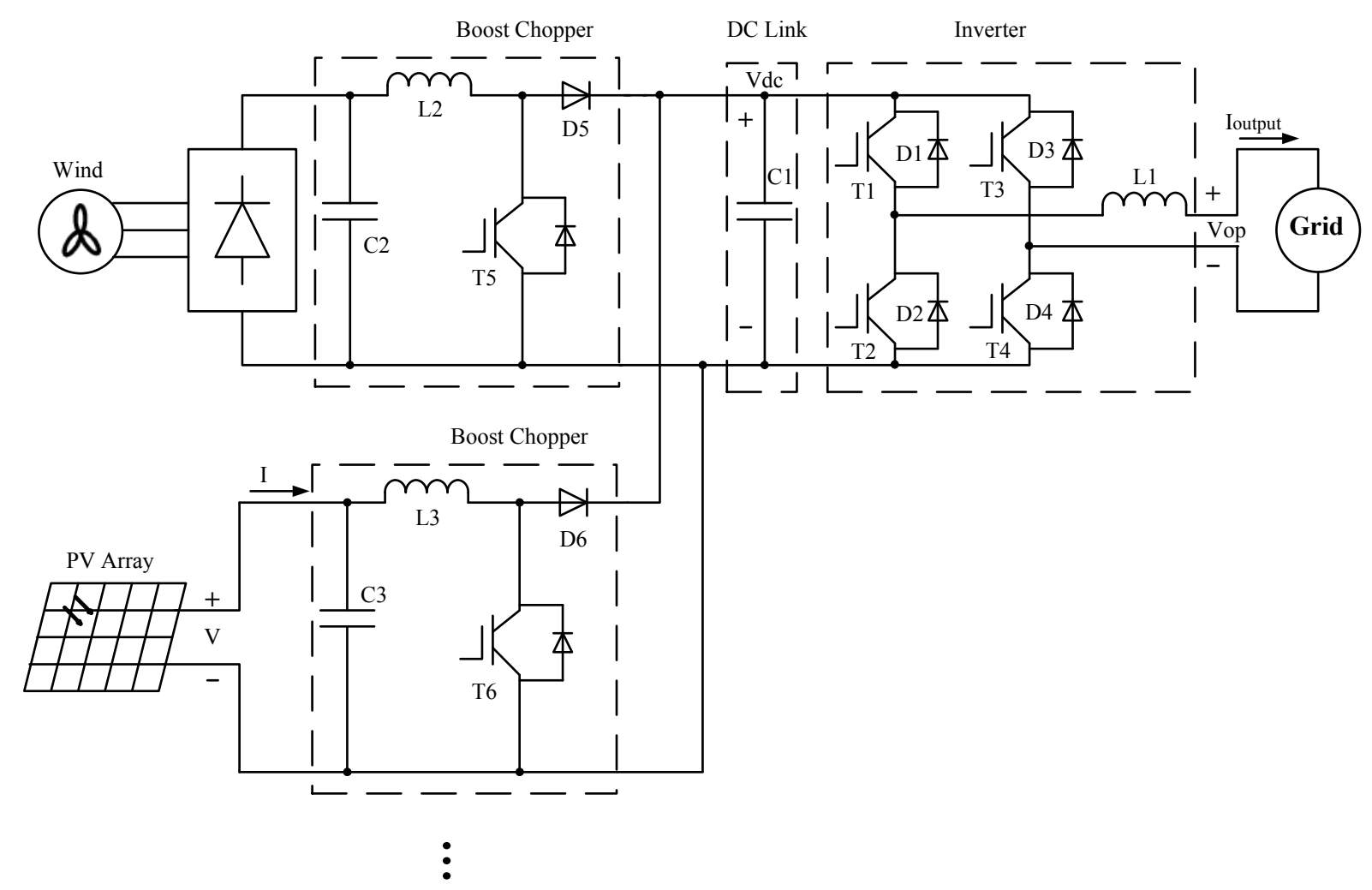

Figure 1. Multi-input system topology.

\subsection{Multi-Input DC/DC Converters}

The multiple-input $\mathrm{dc} / \mathrm{dc}$ converters are used to combine several input power sources whose voltage levels and/or power capacity are different and to get regulated output voltage $[6,7]$. To maximize the power output of the multi-input system, a maximum power extraction strategy is a necessary function of $\mathrm{dc} / \mathrm{dc}$ converter, particularly when the multi-input system has more than two separate input sources. Design of appropriate MPPT algorithms is critical for different input sources so that they do not interfere with each other. As shown in Figure 1, each dc/dc converter has an independent MPPT controller and is controlled individually, whereby all input $\mathrm{dc} / \mathrm{dc}$ converters can be completely decoupled in the control system. This multi-input system has high extendibility and flexibility, making it well suited for hybrid renewable energy applications.

\subsection{Link Module}

The power from all input sources is summed in the dc link module and injected into the grid by one common inverter. At any time, power flow through the entire system should remain balanced. The dc link module plays an important role in maintaining the power flow balance in this multi-input system. As illustrated in Figure 1, the boost choppers are connected to a common inverter via the dc link capacitors (denoted by $C_{1}$ ), which provide a buffer between the instantaneous output power of the boost choppers and the input power of the inverter. It can be found that by applying a constant dc link voltage control strategy, the power injecting into the grid can track rapidly the input power of the multi-input sources through this simple control system.

\subsection{DC/AC Converter}

The dc/ac converter converts the dc power into ac power and should feed high quality sinusoidal ac current into the grid in order to meet interconnection standards [8]. In Figure 1 , the dc/ac converter adopts a full-bridge voltage source inverter (VSI) topology, where insulated gate bipolar transistors (IGBTs) are used as power switching devices due to their low cost and easy control. Base on the conduction states of power switches $T_{1} \sim T_{4}$, the dc/ac converter has four operational modes: two modes in positive grid current period and two modes in negative grid current period (see Table 1) [9]. It can be seen that the output voltage of the inverter $V_{o p}$ can have three values: $V_{o p}(10)=V_{d c}$, $V_{o p}(01)=-V_{d c}$ and $V_{o p}(11)=V_{o p}(00)=0$.

In order to achieve high quality output current feeding into the grid, the dc/ac converter requires an advanced current control algorithm so that it can offer a fast dynamic response to the variations of renewable energy sources and a 
low total harmonic distortion (THD). This paper proposes an improved SVPWM-based predictive current control algorithm specifically for this multi-input single-phase grid-connected inverter.

Table 1. Single-phase grid-connected inverter's operational modes

\begin{tabular}{|c|c|c|c|c|c|c|c|c|}
\hline Mode & $T_{1}$ & $T_{2}$ & $T_{3}$ & $T_{4}$ & $D_{3}$ & $D_{4}$ & $V_{o p}$ & $I_{\text {output }}$ \\
\hline 1 & ON & OFF & OFF & ON & OFF & $\mathrm{OFF}$ & $V_{d c}$ & pos \\
\hline 2 & ON & OFF & OFF & OFF & $\mathrm{ON}$ & OFF & 0 & pos \\
\hline 3 & OFF & $\mathrm{ON}$ & $\mathrm{ON}$ & OFF & OFF & OFF & $-V_{d c}$ & neg \\
\hline 4 & OFF & ON & OFF & OFF & OFF & $\mathrm{ON}$ & 0 & neg \\
\hline
\end{tabular}

\section{Improved SVPWM-Based Predictive Current Control Algorithm}

Most inverters for distributed generation systems are voltage-source current-controlled inverters, where the current feeding into the grid is directly controlled by a PWM strategy $[10,11]$. Three major approaches used for regulating the output current of a VSI are hysteresis, ramp comparison, and predictive current control [12-14]. Of these three, the predictive current control offers the potential for achieving more precise current control with low harmonic distortion [9]. However, it is computationally intensive and may result in poor performance under component parameter variations.

An improved predictive current control scheme has been developed to determine the desired average output voltage of the inverter $V_{o p_{-} a v}$, which is then used to generate the inverter PWM gating signals. The control principle of the improved predictive control methodology is illustrated in Figure 2 [15]. The sampling point is set ahead of the controlling point (i.e. when the control pulses to the inverter power switches are sent out) by a period of the control delay. As a result, the predictive current controller output can be immediately sent to the PWM module for updates and control delay is thus minimized.

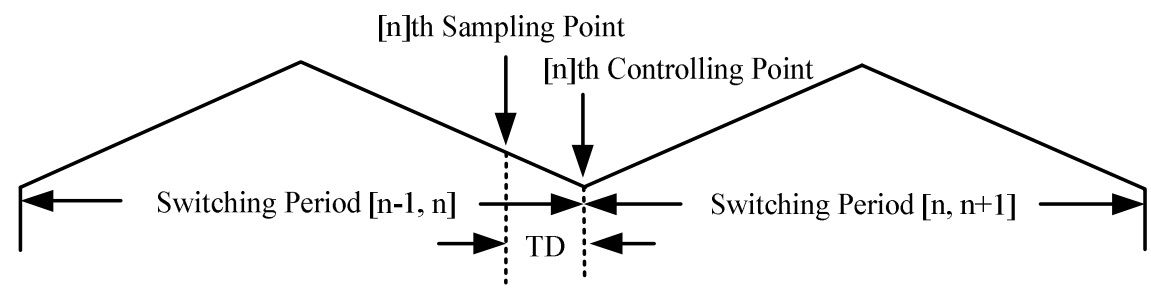

Figure 2. Timing schematic of sampling point and controlling point (TD is a control delay period).

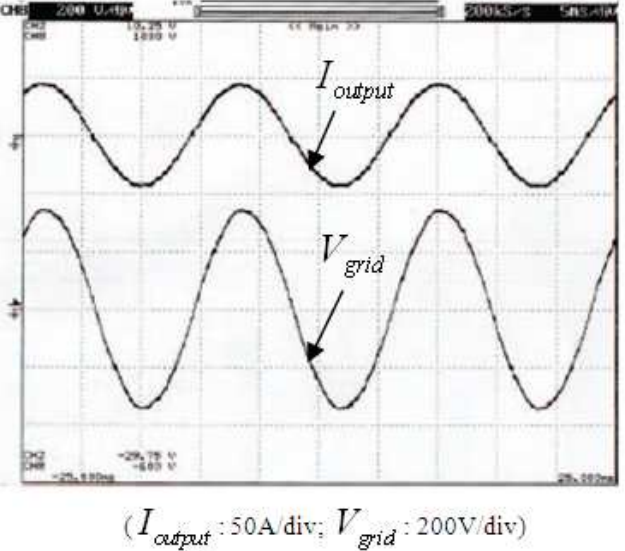

(a)

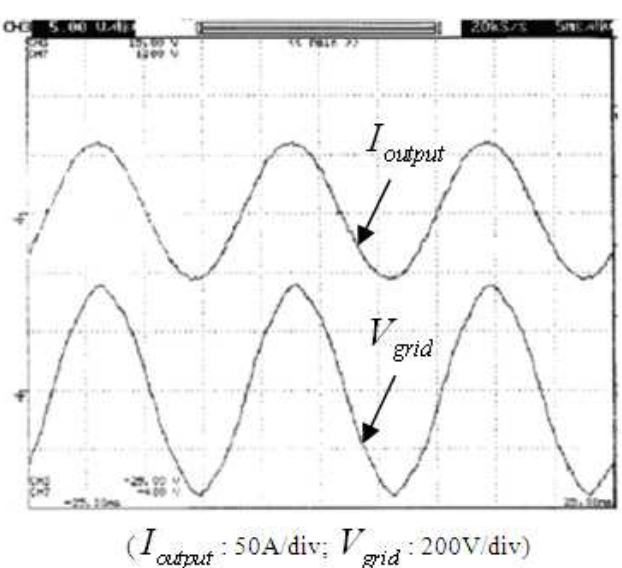

(b)

Figure 3. Inverter output current \& grid voltage waveforms under the SVPWM-based predictive current control. (a) Output power of $7 \mathrm{~kW}$ (b) Output power of $10 \mathrm{~kW}$

Once the demanded average inverter output voltage $V_{o p_{-} a v}$ is calculated, a single-phase centered SVPWM is employed to realize the current modulation of the inverter. This scheme is based on the principle of evenly splitting the switching of IGBTs in each switching cycle among all IGBTs of a full bridge, and thus utilizing a non-simultaneous mode of PWM which doubles the output current ripple frequency [16].

It can be seen that the improved SVPWM-based 
predictive current control algorithm integrates the merits of both split switching PWM strategy and predictive current control strategy. Frequency of power devices and switching losses are reasonably low, and in addition a direct cycle-by-cycle regulation of the current waveform feeding into the grid is provided, resulting in an extremely low total harmonic distortion. Experimental results have verified the benefits of the proposed improved PWM strategy. As shown in Figure $3[5,15]$, at an output power of $7 \mathrm{~kW}$, the measured inverter output current THD is $1.4 \%$; while at an output power of $10 \mathrm{~kW}$, the measured inverter output current THD is $0.9 \%$ even through the grid voltage has a noticeable total harmonic distortion of $2.3 \%$.

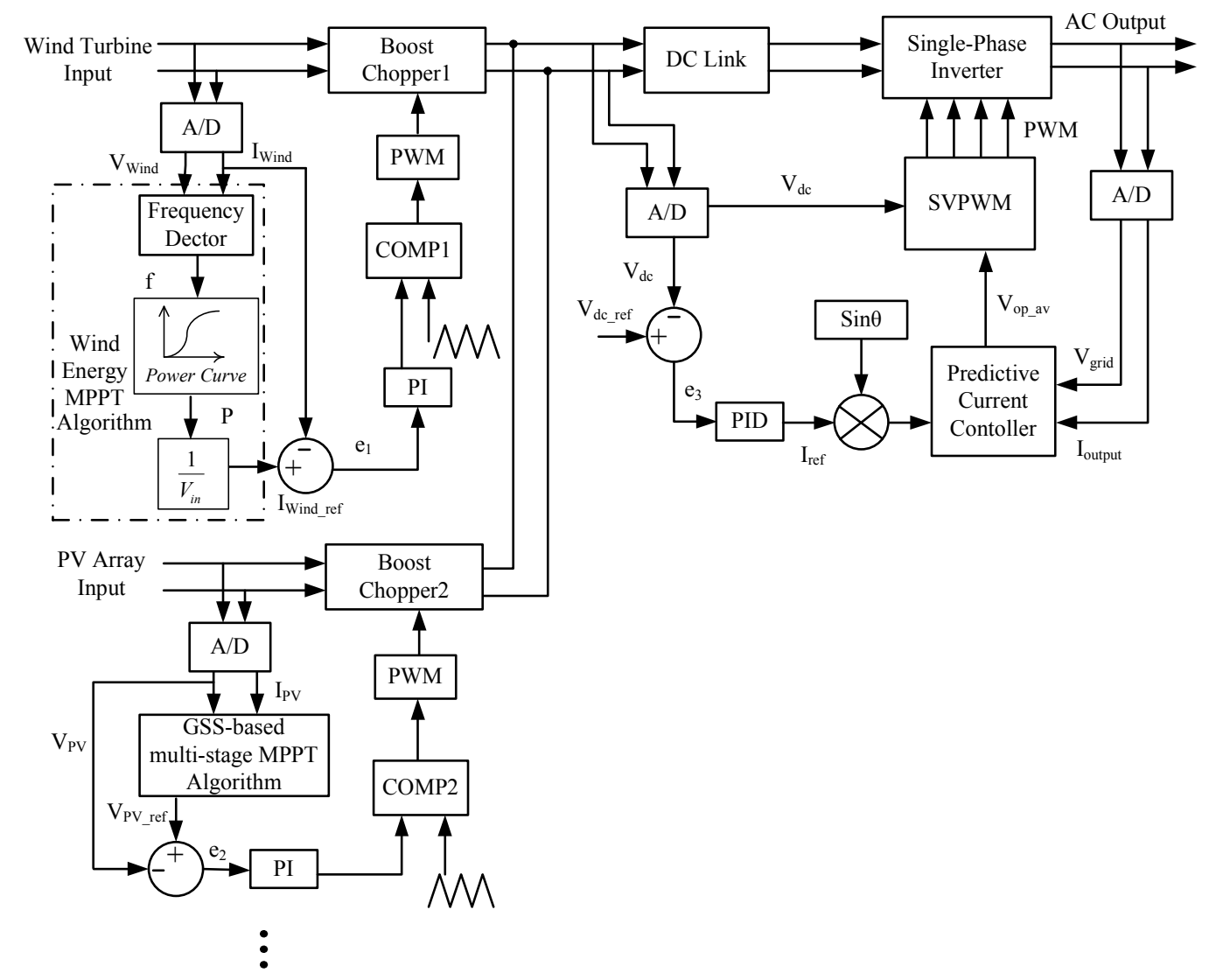

Figure 4. Control block diagram of the developed multi-input inverter.

\section{Control System Implementation}

The control block diagram of the developed multi-input inverter is shown in Figure 4. The hardware implementation of the control circuit is realized by using a digital signal processor (DSP) TMS320LF2407A. The sensed voltage and current values for the PV array and the wind turbine are sent to the DSP, where a multi-stage MPPT algorithm using golden section search (GSS) method [5] determines the reference voltage $V_{P V \text { ref }}$ for the PV array while the wind energy MPPT algorithm determines the reference current $I_{\text {Wind_ref }}$ for the wind turbine. The PWM Comparator1 and Comparator2 generate desired gate signals for power switches $T_{5}$ and $T_{6}$ according to the error signals $e_{1}$ and $e_{2}$, respectively.

The power from all the boost choppers are summed in the dc link module, which cause the variations in the dc link voltage $V_{d c}$. The error signal $e_{3}$ resulting from the comparison between the measured dc link voltage $V_{d c}$ and the reference $V_{d c_{-} r e f}$ feeds to a proportional-integral-derivative (PID) regulator, issuing the inverter output current reference value $I_{r e f}$. The $I_{r e f}$ value and the measured inverter output current $I_{\text {output }}$ and grid voltage $V_{\text {grid }}$ are available for the predictive current controller to calculate the desired average inverter output voltage $V_{o p_{-} a v}$, which is then used to generate PWM gate signals with SVPWM method to four IGBTs of the dc/ac converter for producing sinusoidal ac current.

Note that the dc/ac converter does not need any information from the input modules to control the dc link voltage, which is regulated by controlling the inverter output current. If the measured dc link voltage is less than the reference value, the inverter output current will be decreased in order to increase the dc link voltage, and vice versa. It can 
be seen that the dc link voltage is regulated by the dc/ac converter and the input-output power balance can be achieved in such a way. Note also that the input $\mathrm{dc} / \mathrm{dc}$ converters are modular and individually controlled so that all input converters and the dc/ac converter can be completely decoupled and separated in the control system.

For practical operational considerations, the developed multi-input inverter is equipped with software and hardware protection including the over-current of dc link and inverter output, the over-temperature of IGBTs, the over-voltage of grid, dc link and generator, the under-voltage of grid and generator, the over-frequency and under-frequency of the grid [9]. Figure 5 shows a commercialized product of dual-input hybrid PV/wind inverter. The power rating of this hybrid system is $12 \mathrm{~kW}$ in total with $10 \mathrm{~kW}$ for wind energy and $2 \mathrm{~kW}$ for PV energy.

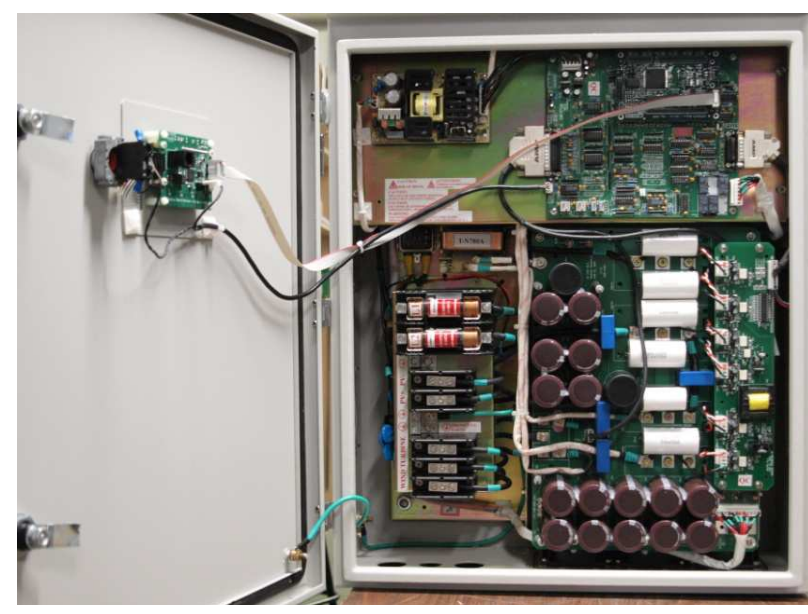

Figure 5. Dual-input hybrid PV/wind inverter.

\section{Experimental Results}

To verify the performance of the developed multi-input single-phase grid-connected inverter, experiments were performed on a real system. The system circuit diagram can be found in Figure 1 and its configuration parameters are as follows: grid voltage is $240 \mathrm{~V}$ and the grid frequency is $60 \mathrm{~Hz}$, dc link voltage is $380 \mathrm{~V}$, output filter inductance $L_{1}$ is $1.48 \mathrm{mH}$, and output power is $12 \mathrm{~kW}$. Switching frequency of IGBTs $\left(T_{5}\right.$ and $\left.T_{6}\right)$ in boost choppers is set at $15 \mathrm{kHz}$ while that of IGBTs $\left(T_{1} \sim T_{4}\right)$ in full-bridge inverter is set at $10 \mathrm{kHz}$.

Figure 6 shows the measured waveforms of gate driving signal $V_{\text {Wind_g }} \&$ inductor current $I_{L 2}$ for the wind turbine, and gate driving signal $V_{P V_{-} g} \&$ inductor current $I_{L 3}$ for the PV array, respectively. It can be found that power switches $T_{5}$ and $T_{6}$ have different conduction times and the lower input voltage require longer inductor charge time in order to obtain the equivalent output voltage (decided by system circuit in Figure 1). It also reveals that the multi-input $\mathrm{dc} / \mathrm{dc}$ converters can deliver power from both of the two energy sources to the dc bus simultaneously.

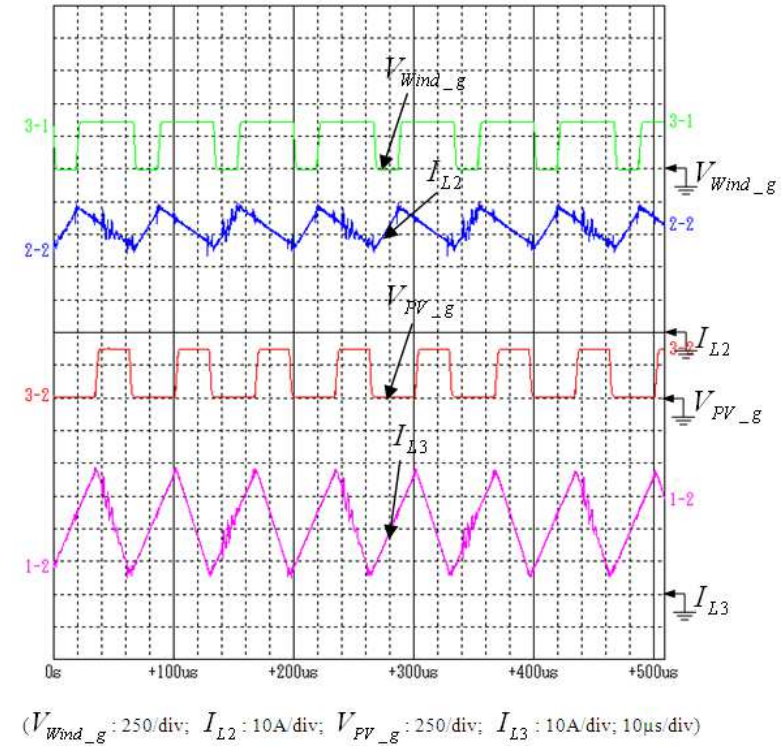

Figure 6. Measured waveforms of gate driving signals and inductor current.

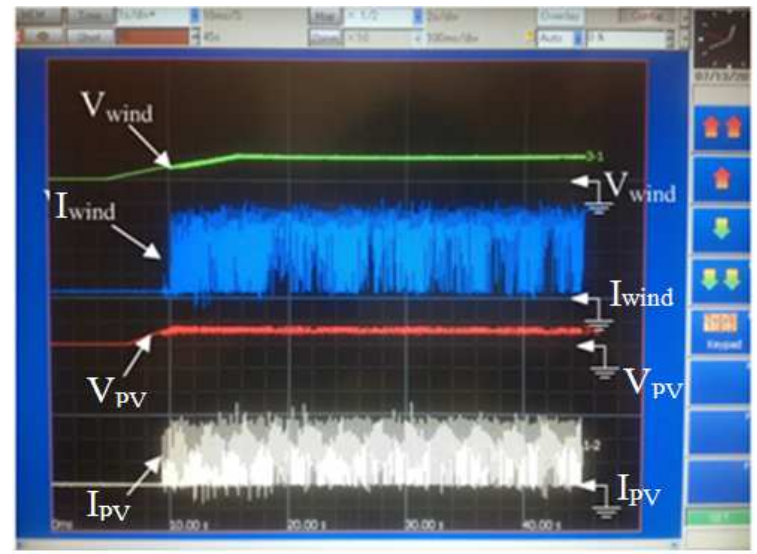

( $V_{\text {wind }}: 250 \mathrm{div} ; I_{\text {Wind }}: 10 \mathrm{~A}$ div $; V_{P V}: 250$ div; $I_{P V}: 10 \mathrm{~A}$ div; 1 s div)

Figure 7. Measured waveforms of voltage anc' current for the PV array and the wind turbine during their startup.

Figure 7 illustrates the waveforms of voltage and current for the PV array and the wind turbine when they are first connected to the multi-input inverter. In Figure 7, the output current of the PV array is increased gradually as determined by the MPPT algorithm with GSS method. Eventually, the output power of the PV array will reach its maximum power point. The output voltage and current waveforms of the wind turbine are very similar to those of PV array. It can be seen that the MPPT features for the PV array and the wind turbine are achieved, respectively.

The transient response of the dc link voltage control is shown in Figure 8. Figure 8(a) illustrates the transient response of the multi-input system when the input power suddenly steps up and Figure 8(b) the case when power steps down. When the system is disturbed by a variation in input power, stable steady state is quickly regained by adjusting the inverter output current. It can be seen that the input-output power balance of the proposed multi-input 
inverter is achieved by keeping the dc link voltage constant.

Figure 9(a) shows the waveforms of the dc link voltage and the inverter output current when only the wind turbine is connected to the multi-input inverter. Initially, the DSP controller sends out the PWM gate signal with MPPT feature

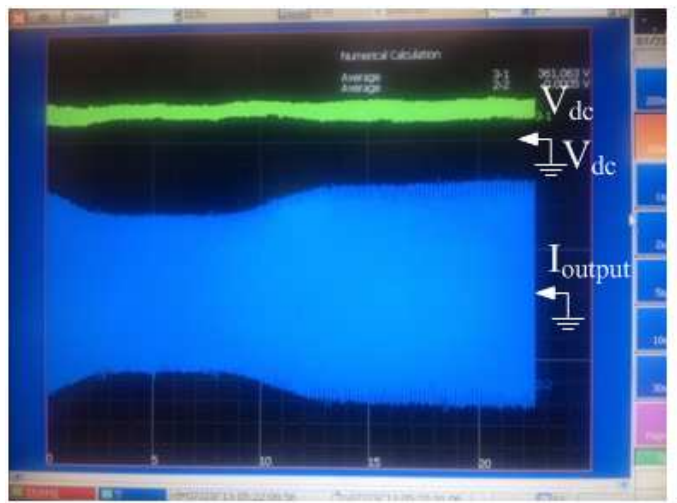

$\left(V_{d c}: 250\right.$ div; $I_{\text {output }}: 10 \mathrm{Adiv} ; 500 \mathrm{~ms}$ div)

(a)

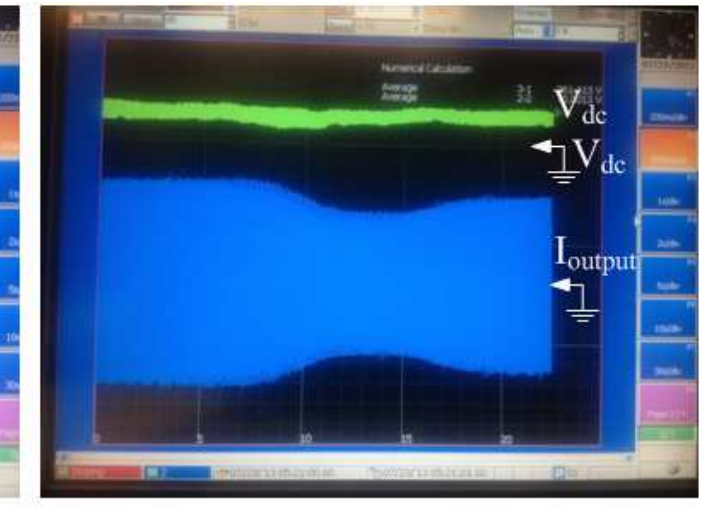

(b)

Figure 8. Experimental transient responses of dc link voltage control. (a) Input power steps up (b) Input power steps down

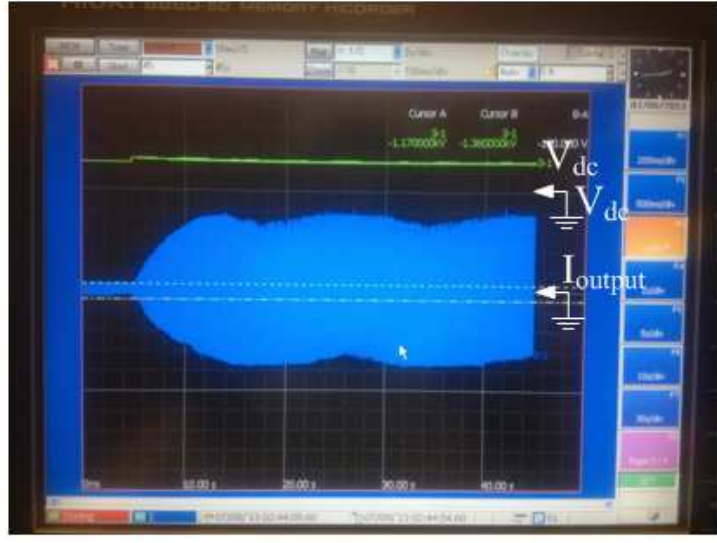

$\left(V_{d c}: 250\right.$ div; $I_{\text {output }}: 10 \mathrm{~A}$ div; $1 \mathrm{~s}$ div $)$

(a)

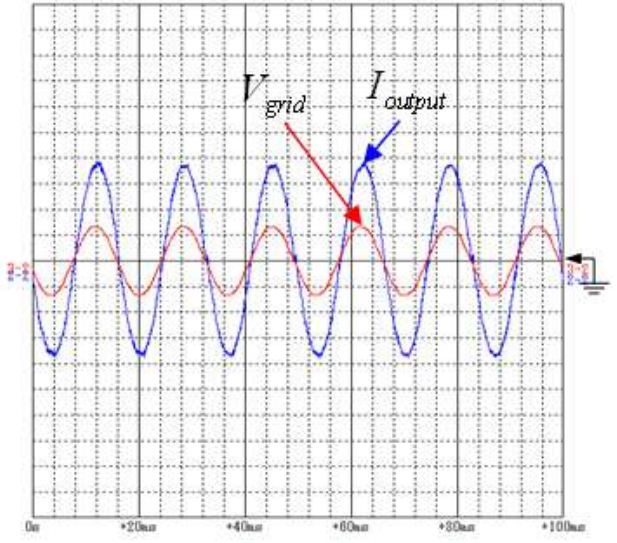

(250/div; $10 \mathrm{~A}$ div; $2 \mathrm{~ms}$ div)

(b)

Figure 9. Waveforms of the developed multi-input inverter when only the wind turbine is supplying power. (a) The dc link voltage and the inverter output current waveforms (b) The expanded grid voltage and inverter output current waveforms

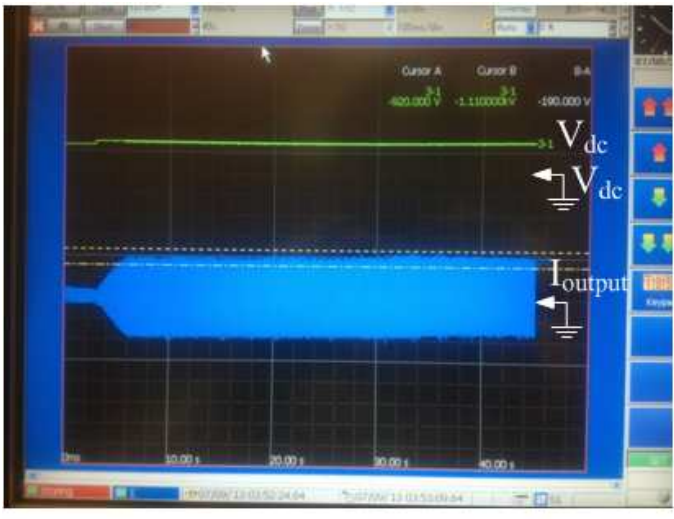

$\left(V_{d c}: 250\right.$ div; $I_{\text {cudput }}: 10 \mathrm{~A}$ div; $1 \mathrm{~s}$ div)

(a)

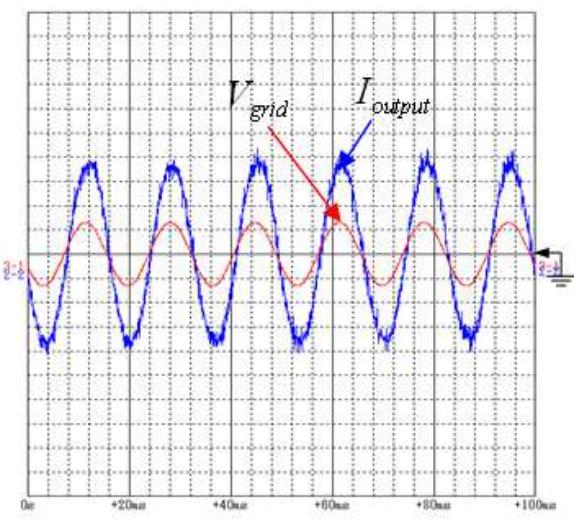

(250 div; $5 \mathrm{~A}$ div; $2 \mathrm{~ms}$ div)

(b)

Figure 10. Waveforms of the developed multi-input inverter when only the PV array is supplying power. (a) The dc link voltage and the inverter output current waveforms (b) The expanded grid voltage and inverter output current waveforms 


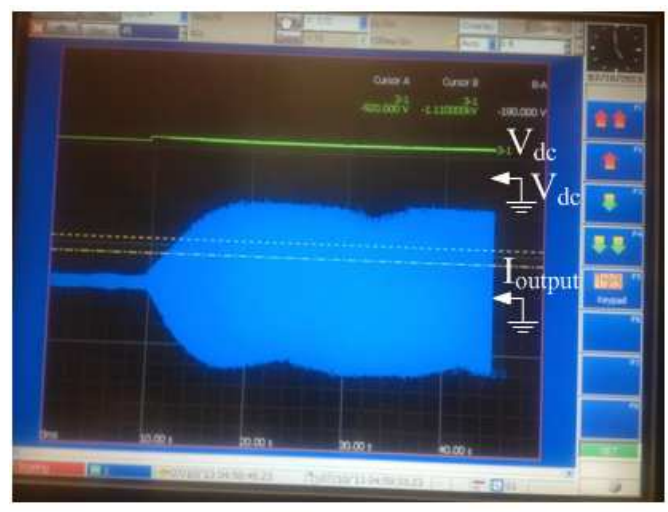

$\left(V_{d c}: 250\right.$ div; $I_{\text {outrut }}: 10 \mathrm{~A}$ div; 1 s/div)

(a)

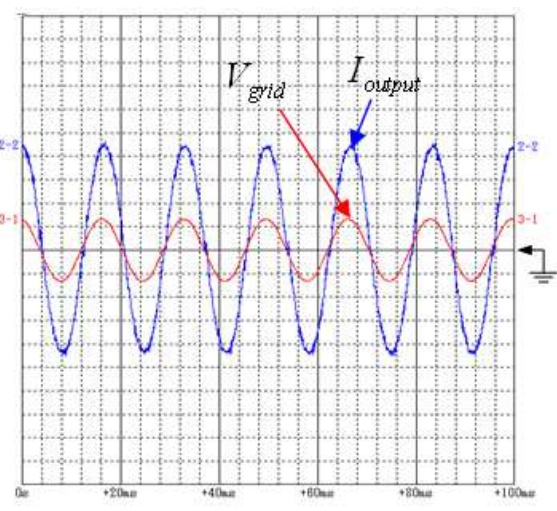

(250/div; $10 \mathrm{~A} /$ div; $2 \mathrm{~ms}$ div)

(b)

Figure 11. Waveforms of the developed multi-input inverter when the PV array and the wind turbine are supplying power. (a) The dc link voltage and the inverter output current waveforms (b) The expanded grid voltage and inverter output current waveforms

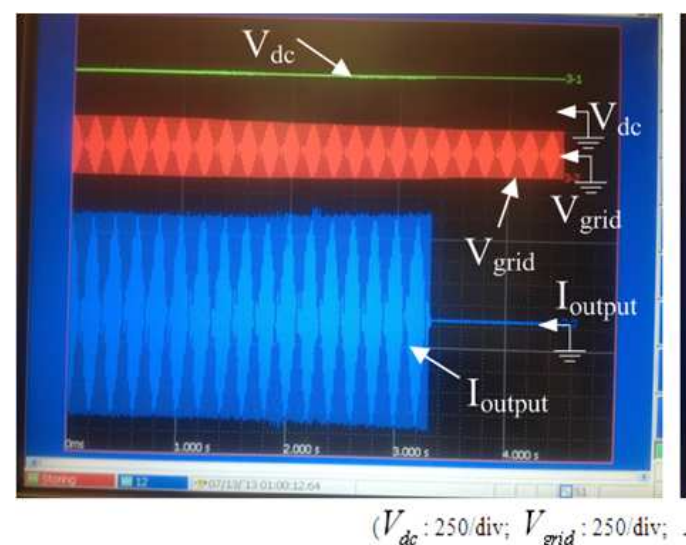

(a)

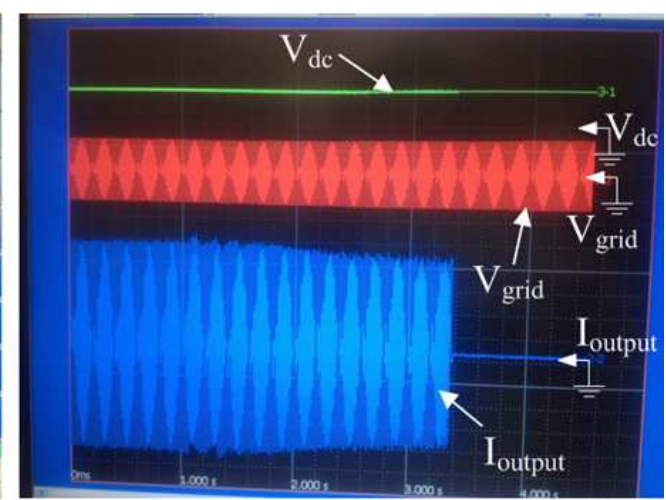

(b)

Figure 12. Some testing waveforms for circuit protection functions. (a) The under-voltage protection (b) The over-voltage protection

Figure 10 shows the similar results when only the PV array is connected to the multi-input inverter. The measured power factor is 0.99 and the current THD is $2.3 \%$. It is noted that the PV array has relatively larger inverter output current ripple. This is due to the fact that the power of the PV array is significantly lower than rated power of the inverter.

Figure 11(a) shows the waveforms of the dc link voltage and the inverter output current when both the PV array and the wind turbine are connected to the proposed multi-input inverter. It can be seen that the output power of the inverter as indicated by the inverter output current varies corresponding to the power adjustment of the MPPT while the dc link voltage remains stable, enabling the inverter to operate with SVPWM-based predictive current control. The expanded grid voltage and inverter output current waveforms are shown in Figure 11(b), where the power factor is 0.99 and the current THD is $1.6 \%$. It is clear that the proposed hybrid PV/wind power system can draw power from the PV array and the wind turbine individually or simultaneously.

For practical applications, many circuit protection functions are realized in the developed multi-input inverter. Figure 12 shows the testing waveforms for under-voltage and over-voltage protection. The multi-input inverter operates when the value of the grid voltage is within the pre-set range. Outside the protection values, output current is interrupted by the inverter protection system.

\section{Conclusions}

A multi-input single-phase grid-connected inverter for hybrid PV/wind power system has been developed by the authors. The operational principle of the proposed multi-input inverter has been introduced. The developed improved SVPWM-based predictive current control algorithm provides a direct cycle-by-cycle regulation of the current waveform feeding into the grid, resulting in an extremely low total harmonic distortion, and yet results relatively low switching frequency of power devices and reasonably low switching losses but also. The control circuit is implemented by using a DSP to accomplish the desired control and protection functions. Experimental results under different operating conditions are shown to verify the performance of the developed multi-input inverter with the desired features: 1) transfer power from the PV array and the wind turbine to the grid individually or simultaneously, 2) implement the MPPT in both solar and wind energy, and 3) allow the power supply system to operate in a wide range of input voltage variation. The multi-input inverter is being 
used in commercial products operating in numerous installations in North America.

\section{List of Symbols}

\begin{tabular}{|c|c|}
\hline$C_{1}$ & dc link capacitors \\
\hline$T_{1} \sim T_{4}$ & power switches in full-bridge inverter \\
\hline$V_{o p}$ & inverter output voltage \\
\hline$V_{o p_{-} a v}$ & average inverter output voltage \\
\hline$I_{\text {Wind }}$ & measured current for the wind turbine \\
\hline$I_{\text {Wind_ref }}$ & reference current for the wind turbine \\
\hline$V_{P V}$ & measured voltage for the PV array \\
\hline$V_{P V_{-} r e f}$ & reference voltage for the PV array \\
\hline$T_{5}$ & power switch in wind turbine's boost chopper \\
\hline$T_{6}$ & power switch in PV array’s boost chopper \\
\hline$e_{1}$ & error signal between $I_{\text {Wind }}$ and $I_{\text {Wind_ref }}$ \\
\hline$e_{2}$ & error signal between $V_{P V}$ and $V_{P V_{-} r e f}$ \\
\hline$V_{d c}$ & de link voltage \\
\hline$V_{d c_{-} r e f}$ & dc link reference voltage \\
\hline$e_{3}$ & error signal between $V_{d c}$ and $V_{d c_{-} r e f}$ \\
\hline$I_{\text {ref }}$ & inverter output reference current \\
\hline$I_{\text {output }}$ & inverter output current \\
\hline$V_{\text {grid }}$ & grid voltage \\
\hline$L_{1}$ & output filter inductance \\
\hline$V_{\text {Wind_g }}$ & gate driving signal for the wind turbine \\
\hline$V_{P V_{-} g}$ & gate driving signal for the PV array \\
\hline$I_{L 2} \quad \mathrm{~b}$ & oost chopper inductor current for the wind turbine \\
\hline$I_{L 3}$ & ost chopper inductor current for the PV array \\
\hline
\end{tabular}

\section{Acknowledgements}

The authors acknowledge the support from Natural Sciences and Engineering Research Council (NSERC) of Canada, Atlantic Innovation Fund, and China Scholarship Council.

\section{References}

[1] Solero L, Caricchi F, Crescimbini F, Honorati O, Mezzetti F. Performance of a $10 \mathrm{~kW}$ power electronic interface for combined wind/PV isolated generating systems. Proceedings of IEEE Power Electronics Specialists Conference, PESC '96, June 23-27, 1996, Baveno, Italy: 1027-1032.

[2] Chen Y, Liu Y, Hung S, Cheng C. Multi-input inverter for grid-connected hybrid PV/Wind power system. IEEE Transactions on Power Electronics 2007; 22(3): 1070-1077.
[3] Wakao S, Ando R, Minami H, et al. Performance analysis of the $\mathrm{PV} /$ wind/wave hybrid power generation system. Proceedings of the 3rd World Conference on Photovoltaic Energy Conversion, May 18-18, 2003, Osaka, Japan: 2337-2340.

[4] Kjaer SB, Pedersen JK, Blaabjerg F. A review of single-phase grid-connected inverters for photovoltaic modules. IEEE Transactions on Industry Applications 2005; 41(5): $1292-1306$

[5] Shao R, Kaye M, Chang L. Advanced building blocks of power converters for renewable energy based distributed generators. Proceedings of the 8th International Conference on Power Electronics and ECCE Asia (ICPE \& ECCE), May 30-June 3, 2011, Jeju, Korea: 2168-2174.

[6] Matsuo H, Lin W, Kurokawa F, Shigemizu T, Watanabe M. Characteristics of the multiple-input DC-DC converter. IEEE Transactions on Industrial Electronics 2004; 51 (3): 625-631.

[7] Khaligh A, Cao J, Lee YJ. A multi-input DC-DC converter topology. IEEE Transactions on Power Electronics 2009; 24(3): 862-868.

[8] Brod DM, Novotny DW. Current control of VSI-PWM inverters. IEEE Transactions on Industry Applications 1985; IA-2(4): 562-570.

[9] Kojabadi HM, Yu B, Gadoura I, Chang L, Ghribi M. A novel DSP-based current controlled PWM strategy for single phase grid connected inverters. IEEE Transactions on Power Electronics 2006; 21(4): 985-993.

[10] Kukrer O. Discrete-time current control of voltage-fed three-phase PWM inverters. IEEE Transactions on Power Electronics 1996; 11(2): 260-269.

[11] Abdel-Rady Y, Mohamed I, EI-Saadany EF. An improved deadbeat current control scheme with a novel adaptive self-tuning load model for a three-phase PWM voltage-source inverter. IEEE Transactions on Industrial Electronics 2007; 54(2): 747-759.

[12] Kazmierkowski MP. Current control techniques for three-phase voltage-source PWM converters: A survey. IEEE Trans Industrial Electronics 1998; 45(5): 691-703.

[13] Holmes DG, Martin DA. Implementation of a direct digital predictive current controller for single and three phase voltage source inverter. Proceedings of IEEE Industry Applications Annual Meeting, October 6-10, 1996, San Diego, CA: 906-913.

[14] Marwali MN, Keyhani A. Control of distributed generation systems-part 1: Voltages and currents control. IEEE Transactions on Power Electronics 2004; 19(6): 1541-1550.

[15] Yu B, Chang L. Improved predictive current controlled PWM for single-phase grid-connected voltage source inverters. Proceedings of IEEE Power Electronics Specialists Conference, PESC '05, June 16-16, 2005, Recife, Brazil: 231-236.

[16] Shao R, Guo Z, Chang L. A PWM strategy for acoustic noise reduction for grid-connected single-phase inverters. Proceedings of the 22nd Annual IEEE APEC, February 25-March 1, 2007, Anaheim, CA, USA: 301-305. 